\title{
PENGARUH SHOPPING LIFESTYLE, USIA DAN GENDER TERHADAP IMPULSE BUYING PRODUK FASHION \\ (SURVEY PADA KONSUMEN PRODUK FASHION DI MALANG TOWN SQUARE (MATOS))
}

\author{
Frengki Kriswardana Putra \\ Department of Management FEB UMM \\ Email: frankyputra@ rocketmail.com
}

\begin{abstract}
The purpose of this study was to examine the influence of shopping lifestyle, age and gender on impulse buying fashion products partially. The population in this study are all consumers who purchase fashion products at Malang Town Square (Matos), located on Jl. Veterans no. 2 Malang. The sample in this study is that consumers fashion products at Malang Town Square (Matos). The sampling method used was purposive sampling method.The analytical tool used to determine the effect of shopping lifestyle, age and gender on impulse buying fashion products at Malang Town Square (Matos) is Factor Analysis and Regression with dummy variables. Hypothesis testing is performed using the $t$ test and the test of the coefficient of determination.Results of Multiple Linear Regression with dummy variables indicating that the shopping lifestyle and gender positive and significant effect on impulse buying fashion products at Malang Town Square (Matos), while age negatively affect impulse buying fashion products at Malang Town Square (Matos). The results of the t test showed that the variables that have the greatest influence is age.
\end{abstract}

Keywords: Shopping Lifestyle, Age, Gender, Impulse Buying, multiple linear regression.

\section{PENDAHULUAN}

Perkembangan zaman yang semakin modern, konsumen dituntut untuk mengikuti perkembangan tersebut. Perkembangan fashion yang semakin menyentuh kehidupan sehari-hari setiap orang. Fashion juga memicu pasar dunia untuk selalu berkembang, produsen dituntut untuk berproduksi dan memenuhi kebutuhan konsumen.

Konsumen tidak selalu melakukan pembelian untuk memenuhi kebutuhannya, akan tetapi konsumen di era modern ini beranggapan bahwa berbelanja merupakan cara menunjukkan status, martabat dan berbelanja untuk kesenangan akan produk terbaru agar tidak ketinggalan zaman, misalnya membeli pakaian yang mahal dan bermerek. Perilaku ini disebut shopping lifestyle.

Japarianto dan Sugiharto (2011) mendefinisikan shopping lifestyle sebagai cara seseorang untuk mengalokasikan waktu dan uang untuk berbagai produk, layanan, 
teknologi, fashion, hiburan dan pendidikan. Strategi pemasaran ditujukan untuk mempengaruhi konsumen agar melakukan pembelian. Proses pembelian yang bersifat rasional, konsumen melakukan pertimbangan yang cermat dan mengevaluasi sifat produk secara fungsional, tetapi konsumen seringkali membeli suatu produk secara tiba-tiba. Perilaku ini tergolong dalam impulse buying atau pembelian impulsif.

Sumarwan (2011:159) dalam penelitian menyatakan bahwa impulse buying adalah perilaku pembelian di mana konsumen tidak mempertimbangkan untuk membeli, atau mempertimbangkan untuk membeli tetapi belum memutuskan produk apa yang akan dibeli. Survei yang dilakukan oleh Point of Purchase Advertising Institute di Amerika Serikat menunjukkan bahwa pada tahun 1995, 70\% melakukan keputusan pembelian di dalam toko dan 68\% di antaranya merupakan impulse buying.

Pembelian impulsif dalam penelitian ini terdiri dari dua dimensi, yaitu dimensi kognitif dan afektif, ketika dikaitkan dengan gender, secara umum banyak yang menganggap bahwa kaum wanita lebih banyak memiliki peran, sementara kaum pria lebih mengandalkan kognisi dalam melakukan pembelian.

Demikian juga dengan faktor usia, semakin tua seseorang, maka pembeliannya akan lebih banyak didasarkan kepada faktor kognisinya. Penelitian sebelumnya mengenai impulse buying yang memiliki hasil yang berbeda dan tidak konsisten pada hasil dari variabel gender dan usia.

Perbedaaan hasil penelitian yang dilakukan Ali dan Hasnu (2013) dalam penelitiannya mengungkapkan bahwa tidak ada perbedaan pada perilaku impulse buying berdasarkan usia, jenis kelamin, sedangkan menurut Ghani dan Farzhan (2010) memiliki hasil yang berbeda yaitu usia dan jenis kelamin memiliki pengaruh negatif terhadap impulse buying. Peneliti selanjutnya yaitu Bashar dkk (2012) memiliki hasil yang berbeda yaitu jenis kelamin, usia, memiliki pengaruh positif terhadap perilaku impulse buying.

Berdasarkan uraian yang telah dikemukakan tersebut, maka peneliti tertarik untuk meneliti dan membuktikan kembali pengaruh gender dan usia terhadap impulse buying yang masih tidak konsisten hasilnya dalam beberapa penelitian terdahulu. Berdasarkan uraian yang telah dikemukakan diatas, maka rumusan masalah yang dapat di ambil adalah (1). Apakah Shopping lifestyle berpengaruh terhadap impulse buying? (2).Apakah usia berpengaruh terhadap impulse buying? (3).Apakah gender berpengaruh terhadap impulse buying?

\section{TINJAUAN PUSTAKA}

Impulse Buying merupakan pembelian konsumen yang berdasarkan segi perencanaannya dikategorikan ke dalam pembelian terencana (planned purchasing) dan pembelian tak terencana atau (unplanned purchasing/ impulse buying behavior).

Pembelian terncana yaitu perilaku pembelian di mana keputusan tentang 
item yang akan dibeli telah diambil sebelum konsumen masuk ke dalam toko, sedangkan pembelian tidak terencana adalah perilaku pembelian di mana konsumen tidak mempertimbangkan untuk membeli atau mempertimbangkan untuk membeli tapi belum memutuskan produk apa yang akan dibeli.

Coob dan Hayer (1986), mengklasifikasikan suatu pembelian impulsif terjadi apabila tidak terdapat tujuan pembelian merek tertentu atau kategori produk tertentu pada saat masuk ke dalam toko. Beberapa peneliti pemasaran beranggapan bahwa impulsebersinonim dengan unplanned ketika para psikolog dan ekonom memfokuskan pada aspek irasional atau pembeli impulsif murni (Bayley dan Nancarrow, 1998).

Menurut Loudon dan Bitta (1993), "Impulse buying or unplanned purchasing is another consumer purchasing pattern. As the term implies, the purchase that consumers do not specifically planned". Ini berarti bahwa impulse buying merupakan salah satu jenis perilaku konsumen, dimana hal tersebut terlihat dari pembelian konsumen yang tidak secara rinci terencana.

Keputusan pembelian yang dilakukan belum tentu direncanakan, terdapat pembelian yang tidak direncanakan (impulse buying) akibat adanya rangsangan lingkungan belanja. Implikasi dari lingkungan belanja terhadap perilaku pembelian mendukung asumsi bahwa jasa layanan fisik menyediakan lingkungan yang mempengaruhi perilaku konsumen, dihubungkan dengan karakteristik lingkungan konsumsi fisik (Bitner, Booms, dan Tetreault, 1990).

Pembuatan keputusan dalam pembelian impulsif dipengaruhi oleh masalah kognisi dan afeksi dalam diri seseorang, di mana segi afeksi lebih memiliki peran dibanding sisi kognisi. Impulsif ini sulit dibendung karena sering melibatkan pengalaman yang menyenangkan, sesuai dengan penelitian yang dilakukan oleh Lumintang (2012) yang meyebutkan bahwa hedonic motives berpengaruh secara signifikan terhadap impulse buying, sehingga konsumen tidak akan mempertimbangkan suatu manfaat dari produk tersebut. Jadi, pembelian impulsif adalah pembelian yang sebelumnya tidak direncanakan dan terjadi secara spontan karena munculnya dorongan yang kuat untuk membeli dengan segera.

Penelitian yang dilakukan Ali dan Hasnu (2013), meneliti tentang analisis karakteristik konsumen pada perilaku pembelian impulsif di Pakistan. Variabel yang diteliti antara lain usia, jenis kelamin, pendapatan, orientasi geografis dan orientasi budaya dengan menggunakan alat analisis ANOVA. Hasil penelitiannya menunjukkan bahwa tidak adavariabel yang signifikanyang ditelitiyang dapat mempengaruhikonsumen untuk melakukan perilaku impulse buying.

Ghani dan Farzhan (2010), melakukan penelitian dengan judul An Exploratory Study of the Impulse Buying Behaviour of Urban Consumers in Peshawar, dalam penelitian ini penulis menggunakan alat analisis regresi linier dengan variabel dummy. Hasil penelitiannya menyebutkan bahwa usia dan jenis kelamin memiliki pengaruh negatif 
terhadap impulse buying sedangkan pendapatan memiliki pengaruh positif terhadap impulse buying tetapi tidak signifikan. Untuk variabel usia bisa diasumsikan bahwa semakin tua usia sesorang maka pembelian impulsifnya rendah atau sebaliknya, sedangkan untuk variabel jenis kelamin bisa diasumsikan tidak ada perbedaan perilaku impulse buying berdasarkan jenis kelamin, akan tetapi asumsi semua orang secara umum menyebutkan bahwa wanita lebih impulsif daripada pria.

Penelitian selanjutnya yaitu dilakukan oleh Bashar dkk (2012) yang meneliti tentang faktor demografi yaitu jenis kelamin, usia, pendapatan, pekerjaan dan pendidikan. Hasilnya menunjukkan bahwa semua variabel yang diteliti yaitu jenis kelamin, usia, pendapatan, pekerjaan dan pendidikan memiliki pengaruh positif terhadap perilaku impulse buying. Untuk variabel usia menghasilkan asumsi bahwa semakin bertambahnya usia maka perilaku impulsifnya semakin tinggi.

Perbedaan hasil penelitian dengan penelitian sebelumnya yang menyatakan bahwa tidak ada perbedaan pada perilaku impulse buying berdasarkan usia, jenis kelamin, pendapatan, orientasi geografis dan orientasi budaya, sedangkan peneliti selanjutnya mengungkapkan bahwa usia dan jenis kelamin memiliki pengaruh negatif terhadap impulse buying, sedangkan pendapatan memiliki pengaruh positif. Peneliti lainnya juga menunjukkan perbedaan hasil yaitu jenis kelamin, usia, pendapatan, pekerjaan dan pendidikan memiliki pengaruh positif terhadap perilaku impulse buying.
Karakteristik pembelian impulsif yang disebutkan Engel dan Blackwell (1995), yaitu: Spontanitas, pembelian ini tidak diharapkan sebelumnya dan memotivasi konsumen untuk membeli saat itu juga, serta langsung merespon pointof-sale yang terangsang secara visual, Kekuatan, kompulsi, dan intensitas, konsumen termotivasi untuk mengesampingkan semua sehingga mendorong melakukan pembelian dan bertindak dengan segera, Kegairahan dan stimulasi, keinginan yang datang tiba-tiba untuk membeli disertai oleh adanya emosi yang dikarakteristikkan dengan perasaan "bergairah", "sensasi" atau "liar/tidak terkendali. d. Mengabaikan konsekuensi, keinginan untuk membeli yang tidak dapat ditahan serta berpotensi untuk mengabaikan konsekuensi negative.

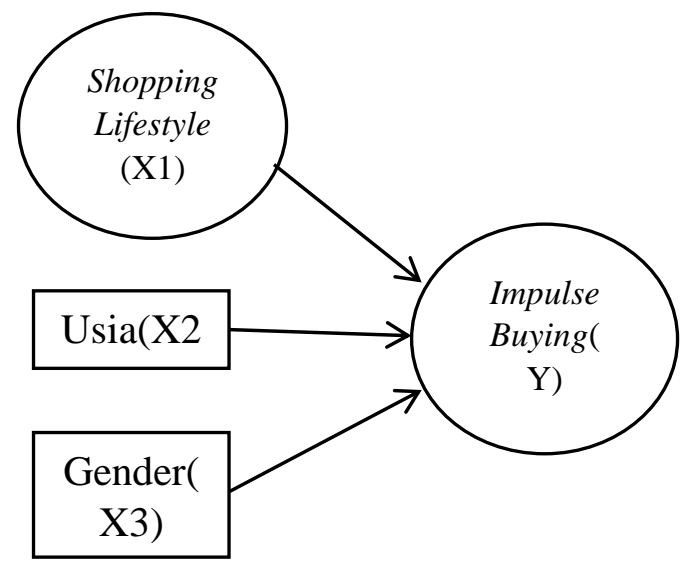

Gambar 1. Model Konseptual

Shopping lifestyle adalah salah satu gaya hidup seseorang yang memanfaatkan waktu dan uang untuk melakukan berbagai kegiatan seperti berbelanja, liburan dan pendidikan. Japarianto (2011)mendefinisikan Shopping lifestyle sebagai cara seseorang untuk mengalokasikan 
waktu dan uang untuk berbagai produk, layanan, teknologi, fashion, hiburan dan pendidikan. Shopping lifestyle ini juga ditentukan oleh beberapa faktor antara lain sikap terhadap merek, pengaruh iklan dan kepribadian.

Cathy J. Cobb dan Wayne D. Hoyer (1986) mengungkapkan bahwa konsumen diminta untuk menunjukkan sejauh mana mereka sepakat atau tidak setuju dengan pernyataan yang berkaitan dengan shopping lifestyle (misalnya, sikap terhadap merk nasional, dirasakan pengaruh iklan, harga kesadaran). Betty Jackson (2004) mengatakan shopping lifestyle merupakan ekspresi tentang lifestyle dalam berbelanja yang mencerminkan perbedaan status sosial.

Cobb dan Hoyer (1986) mengemukakan bahwa untuk mengetahui hubungan shopping lifestyle terhadap impulse buying behavior adalah dengan menggunakan indikator: Menanggapi untuk membeli setiap tawaran iklan mengenai produk fashion, Membeli produk model terbaru ketika melihatnya, Berbelanja merek yang paling terkenal, Yakin bahwa merek (produk kategori) terkenal yang dibeli terbaik dalam hal kualitas, Sering membeli berbagai merek (produk kategori) daripada merk yang biasa di beli, yakin ada dari merek lain (kategori produk) yang sama seperti yang di beli.

Shopping lifestyle adalah salah satu gaya hidup seseorang yang memanfaatkan waktu dan uang untuk melakukan berbagai kegiatan seperti berbelanja, liburan dan pendidikan. Cara konsumen dalam berbelanja untuk memenuhi kebutuhannya semakin mengalami peningkatan, hal ini menunjukan bahwa berbelanja telah menjadi sebuah gaya hidup untuk kebanyakan orang saat ini. Konsumen akan rela mengorbankan sesuatu demi memenuhi lifestyle dan hal tersebut akan cenderung mengakibatkan perilaku impulse buying (Japarianto, 2011).

Berdasarkan teori yang telah dikemukakan maka dapat dirumuskan suatu hipotesis yaitu:

H1: Shopping lifestyle berpengaruh terhadap impulse buying

Demografi (demography), dari segi kata, merupakan istilah yang berasal dari dua kata Yunani, yaitu demos yang berarti rakyat atau penduduk dan grafien yang berarti menggambar atau menulis. Oleh karena itu, demografi dapat diartikan sebagai tulisan atau gambaran tentang penduduk.Istilah ini pertama kali dipakai oleh Achille Guillard pada tahun 1855 dalam karyanya yang berjudul "Element de statistique Humaine, ou Demography Comparee".

Kebutuhan dan selera seseorang akan berubah sesuai dengan bertambahnya usia. Pembelian dibentuk oleh tahap siklus hidup keluarga, sehingga pemasar perlu memperhatikan perubahan minat pembelian yang berhubungan dengan daur siklus hidup manusia. Secara umum orang beranggapan bahwa pada suatu titik usia dimana seseorang akan mengalami penurunan pembelian.

Wood (1998) yang mengungkapkan bahwa pembelian impulsif juga dipengaruhi oleh karakteristik personal, yaitu usia, pembelian impulsif meningkat pada usia 18 hingga 39 tahun dan menurun 
setelahnya. Rentang usia 18-39 tahun adalah rentang usia yang termasuk dalam tahap perkembangan dewasa awal.

Philip Kotler (2000) mengatakan bahwa kebutuhan dan keinginan konsumen berubah seiring dengan perubahan usianya. Konsumen muda cenderung lebih impulsif dibandingkan dengan konsumen yang lebih tua. Rasa penasaran dan ingin mencoba sesuatu yang baru, membuat konsumen muda menjadi lebih impulsif. Konsumen muda lebih cenderung menjadi pelopor dalam mengadopsi gaya hidup baru, membeli produk baru dan modis, dan menikmati berbelanja di tempat baru yang diperkirakan dapat lebih mendorong mereka untuk melakukan pembelian impulsif.

Menurut Sadli dalam

Sumarwan (2011) mengungkapkan bahwa gender adalah semua atribut sosial mengenai pria dan wanita, misalnya pria digambarkan memiliki sifat maskulin seperti keras, kuat, rasional dan gagah, sementara wanita digambarkan memiliki sifat feminim seperti halus, lemah, perasa, sopan dan penakut. Wanita lebih banyak menghabiskan waktunya sekedar untuk jalan-jalan di pusat perbelanjaan, meskipun tidak ada niat untuk berbelanja. Wanita lebih mempunyai banyak kesempatan untuk terkena stimuli impulsif sehingga sangat memungkinkan bagi wanita untuk lebih sering melakukan pembelian impulsif.

Berdasarkan teori yang telah dikemukakan maka dapat dirumuskan suatu hipotesis yaitu:

$\mathrm{H} 2$ : Usiaberpengaruh terhadap Impulse Buying
H3: Gender berpengaruh terhadap Impulse Buying

\section{METODE PENELITIAN}

Lokasi yang dipilih sebagai tempat penelitian adalah Malang Town Square (Matos) yang berlokasi di Jl. Veteran no. 2 Kota Malang.

Dalam penelitian ini variabel yang akan diteliti terdiri dari empat variabel, yaitu Shopping Lifestlye (X1), yaitu Cara seseorang untuk mengalokasikan waktu dan uang untuk berbagai produk, layanan, teknologi, fashion, hiburan atau kesenangan. Variabel ini di ukur menggunakan dimensi AIO (activity, interest, opinions), Usia (X2), merupakan identitas usia responden. Variabel ini di ukur menggunakan usia sebenarnya dari responden, Gender (X3), merujuk pada karakteristik atau data-data konsumen yang terdiri dari wanita dan pria, Impulse Buying (Y), yaitu Pembelian yang sebelumnya tidak direncanakan dan terjadi secara spontan, Variabel ini di ukur menggunakan indikator, spontanitas pembelian. kekuatan, kompulsi dan intensitas, kegairahan dan stimulasi. mengabaikan konsekuensi.

Populasi dalam penelitian ini adalah seluruh konsumen yang melakukan pembelian produk fashion di Malang Town Square (Matos). Jumlah sampel pada penelitian ini adalah sebanyak 100 responden.Metode penarikan sampel yang digunakan dalam penelitian ini menggunakan metode nonprobability dan purposive sampling.

Analisis data pada penelitian ini yaitu menggunakan Analisis Regresi Linier Berganda dan Analisis Faktor, sebelum kuesioner diberikan kepada 
100 responden,penulis melakukan try out terhadap 30 responden dengan memberikan 24 butir pertanyaan untuk menguji tingkat validitas dan reliabilitas dari seluruh instrumen dan melakukan uji asumsi klasik sebagai syarat dari analisis regresi linier berganda.

\section{HASIL PENELITIAN DAN PEMBAHASAN}

Hasil uji validitas dan uji reliabilitas variabel Shopping lifestyle dan Impulse buying menunjukkan bahwa semua instrumen data variabel Shopping Lifestyle dan impulse buying yang digunakan adalah valid dan reliabel dan pada uji asumsi klasik yang terdiri dari uji multikolinieritas, uji heteroskedastisitas dan uji normalitas menunjukkan bahwa dari semua uji yang dilakukan bebas dari asumsi klasik dan layak untuk melakukan analisis regresi linier berganda. Berikut adalah hasil analisis regresi linier berganda:

Tabel 1. Hasil Analisis Linier Berganda

\begin{tabular}{lccccc}
\hline \multirow{2}{*}{ Model } & \multicolumn{2}{c}{ Und. Coeff } & Std.coeff & & t \\
\cline { 2 - 4 } & $\mathrm{B}$ & Std.error & Beta & & \\
\cline { 2 - 4 } & & & & & \\
Shopping L.style & 1.422 & .170 & .233 & 8.379 & .000 \\
Usia & .233 & .072 & -.604 & 3.251 & .002 \\
Gender & -.053 & .005 & .230 & -11.5 & .000 \\
& .472 & .130 & & 3.632 & .000 \\
\hline
\end{tabular}

Dari hasil uji diatas, maka diperoleh persamaan regresi sebagai berikut: $\mathrm{Y}=1,422+0,233$

$\mathrm{X}_{1}+(-0,604) \mathrm{X}_{2}+0,230 \mathrm{D}_{1}$

Keterangan:

$$
\begin{aligned}
& \mathrm{Y}=\text { Impulse buying } \\
& X_{1} \quad=\text { Shopping lifestyle } \\
& X_{2} \quad=\text { Usia, } \\
& D_{1} \quad=\text { Dummy gender } \\
& \alpha \quad=\text { Konstanta } \\
& \beta_{1}, \beta_{2}, \beta_{3}=\text { Koefisien estimasi }
\end{aligned}
$$

Interpretasi dari model regresi adalah: Konstanta ( $\alpha)$ : Tanpa dipengaruhi variabel Shopping lifestyle, usia dan gender, maka variabel impulse buying sama dengan
1,422. Koefisien $\left(\beta_{1}\right)$ : Jika variabel Shopping lifestyle (X1) meningkat dengan asumsi variabel lainnya bernilai tetap, maka variabel impulse buying (Y) akan meningkat. Koefisien $\left(\beta_{2}\right)$ :Jika variabel Usia(X2) meningkat sebesar 1 (satu) satuan dengan asumsi variabel lainnya bernilai tetap, maka variabel impulse buying (Y) akan menurun.Koefisien $\left(\beta_{3}\right)$ : Nilai Koefisien $\left(\beta_{3}\right)$ variabel gender (X3) memiliki pengaruh positif terhadap impulse buying (Y), maka dalam hal ini wanita memiliki perilaku impulse buying yang lebih tinggi daripada pria dan terdapat 
perbedaan perilaku impulse buying berdasarkan gender.

Pengujian hipotesis menggunakan koefisien determinasi menunjukkan bahwa Nilai besarnya Adjusted $R$ Square adalah 0,822 $(82,2 \%)$ yang memiliki arti bahwa variabel Shopping lifestyle (X1), Usia (X2) dan Gender (X3) memiliki pengaruh sebesar $82,2 \%$ terhadap Impulse Buying konsumen produk fashion di Malang Town Square, sedangkan pada uji t menujukkan bahwa Nilai t hitung pada variabel Shopping Lifestyle adalah 3,251 dengan tingkat signifikan 0,002. Karena 3,251 > 1,985 dan 0,002 < 0,05 . Maka dapat disimpulkan bahwa H0 ditolak dan Ha diterima.Jadi Hipotesis pertama (H1) Shopping Lifestyle berpengaruh terhadap Impulse Buying dapat diterima.Nilai $\mathrm{t}$ hitung pada variabel Usia adalah 11,532 dengan tingkat signifikan 0,000 . Hasil penelitian menunjukkan bahwa variabel usia berpengaruh negatif dan signifikan terhadap Impulse Buying. Jadi hipotesis kedua (H2) Usia berpengaruh terhadap impulse buying dapat diterima. Variabel Usia berpengaruh secara negatif.Nilai t hitung pada variabel Gender adalah 3,632 dengan tingkat signifikan 0,000. Karena 3,632 > 1,985 dan $0,000<0,05$. Maka dapat disimpulkan bahwa H0 ditolak dan Ha diterima.Jadi hipotesis ketiga (H3) Gender berpengaruh terhadap impulse buying dapat diterima.

Hipotesis pertama $(\mathrm{H} 1)$ yang menyatakan Shopping lifestyle berpengaruh positif terhadap Impulse buying di Malang Town Square (MATOS) dapat diterima. Dari hasil analisis menunjukkan bahwa Shopping lifestyle berpengaruh positif dan signifikan terhadap Impulse buying di Malang Town Square (MATOS). Hal ini berarti bahwa pelanggan cenderung melakukan pembelian impulsif produk fashion di Malang Town Square (MATOS) apabila menghabiskan waktu yang lama, sering berbelanja, memiliki uang banyak untuk berbelanja, tertarik pada fashion terbaru dan produk fashion merek terkenal serta menganggap bahwa fashion mencerminkan identitas diri dalam kehidupan masyarakat yang menyebabkan terciptanya perilaku Impulse buying.

Hasil hipotesis kedua (H2) yang menyatakan bahwa Usia berpengaruh terhadap Impulse buying dapat diterima. Dari hasil analisis menunjukkan bahwa usia berpengaruh negatif signifikan terhadap impulse buying.Hal ini menunjukkanbahwa semakin bertambahnya usia konsumen, maka pembelian impulsifnya akan semakin menurun, dan begitujuga sebaiknya.

Hasil hipotesis ketiga (H3) yang menyatakan bahwa Gender berpengaruh terhadap impulse buying dapat diterima. Dari hasil analisis menunjukkan bahwa gender berpengaruh positif terhadap perilaku impulse buying, sehingga dapat disimpulkan terdapat perbedaan yang signifikan antara gender (wanita dan pria)dengan pengaruhnya terhadap konsumen dalam melakukan pembelian impulsif.

Shopping lifestyle adalah salah satu gaya hidup untuk memanfaatkan waktu dan uang (aktivitas), semakin seseorang menghabiskan waktu yang lama dan sering berbelanja di Malang Town Square (MATOS), maka kecenderungan untuk melakukan 
pembelian produk fashion secara impulsif akan semakin tinggi, banyak faktor yang mempengaruhi konsumen untuk melakukan pembelian tidak terencana, misalkan karena konsumen melihat produk fashion yang disukai dan tanpa berfikir panjang dan mengesampingkan kegunaannya, begitu juga ketika seseorang semakin sering berkunjung dengan memiliki uang yang banyak, maka kemungkinan untuk berbelanja secara impulsif semakin tinggi.

Perilaku pembelian impulsif produk fashion tidak hanya terjadi karena aktivitas dan minat saja, melainkan bagaimana pandangan seseorang terhadap fashion tersebut (pendapat) dihubungkan dengan kehidupan sehari-harinya, misalkan dengan menggunakan produk fashion terkenal dapat mencerminkan identitas diri dalam kehidupan masyarakat, pandangan tersebut dapat mempengaruhi pola perilaku pembeliannya, sebisa mungkin seseorang akan memenuhi kebutuhannya dan ketika melihat produk fashion yang terkenal, mereka akan antusias dan merasa harus memilikinya saat itu juga (spontan), serta mengabaikan konsekuensi negatif.

Lokasi Malang Town Square (MATOS) yang berada dekat dengan kampus yang didominasi oleh mahasiswa, memiliki pengaruh tersendiri terhadap gaya hidup mereka, karena kemudahan akses dan dekatnya lokasi dengan Malang Town Square (MATOS), sehingga mahasiswa memiliki kecenderungan untuk sering mengunjungi Malang Town Square (MATOS) walaupun tidak berkeinginan untuk berbelanja dan hanya sekedar jalan-jalan, hal ini yang memungkinkan terjadinya pembelian secara impulsif.

Hasil penelitian ini sesuai dengan penelitian yang dilakukan oleh Ghani dan Farzhan (2010) yang menyebutkan bahwa usia memiliki pengaruh negatif terhadap perilaku impulse buying, artinya semakin tua seseorang maka semakin rendah kecenderungan untuk pembelian impulsifnya.

Wood (1998) menemukan bahwa pembelian impulsif meningkat pada usia 18 hingga 39 tahun dan menurun setelahnya. Rentang usia 1839 tahun adalah rentang usia yang termasuk dalam tahap perkembangan dewasa awal. Kota Malang adalah kota pelajar dengan banyaknya kampus dan didominasi oleh mahasiswa yang rata-rata masih muda, hal ini memungkinkan konsumen di Malang Town Square (MATOS) didominasi oleh mahasiswa yang memiliki usia yang muda, gaya hidup modern dan lokasi Malang Town Square (MATOS) yang berdekatan dengan kampus yang menyebabkan kecenderungan untuk melakukan pembelian produk fashion tinggi.

Variabel kontrol jenis kelamin menggunakan dummyvariabel (0 untuk pria dan 1 untuk wanita), yang berarti wanita memberikan pengaruh yang signifikan terhadap pembelian impulsif, maka dapat diputuskan bahwa konsumen wanita lebih sering melakukan pembelian impulsif dibandingkan konsumen pria. Mayoritas konsumen Malang Town Square (MATOS) adalah dari kalangan mahasiswa, selain dikenal dengan sebutan kota pelajar juga lokasi Malang Town Square (MATOS) berdekatan dengan 
kampus dan didominasi oleh populasi mahasiswa.

Anggapan bahwa kaum wanita adalah kaum pembelanja terbesar, tidak sepenuhnya datang dari kaum wanita itu sendiri, sebab penawaran produk-produk yang ditujukan pada wanita sering kali tidak didasarkan pada kebutuhan wanita tetapi lebih merupakan penawaran gaya hidup pada kelas sosial tertentu. Produk yang ditawarkan tidak jarang mendikte dan mempengaruhi wanita untuk menjadi ideal dan modern dengan produk-produk fashion yang ditawarkan, misalnya pakaian dan produk kecantikan. Wanita secara umum beranggapan bahwa wanita yang cantik adalah harus berkulit putih, langsing, tidak berjerawat dan menggunakan pakaian modern yang menjadi trend.

Untuk menjaga kecantikannya, wanita harus menggunakan produkproduk kecantikan dan ketika mereka berada di pusat perbelanjaan dan melihat penawaran-penawaran yang menggiurkan, seperti model fashion terbaru mereka cenderung akan melakukan pembelian secara impulsif. Berdasarkan hal tersebut, wanita rela membelanjakan uangnya lebih banyak daripada kaum pria, hal ini memungkinkan bahwa wanita lebih memiliki peluang untuk melakukan pembelian impulsif.

\section{SIMPULAN}

Simpulan dari penelitian ini yaitu :Shopping Lifestyle (X1) berpengaruh positif dan signifikan terhadap impulse buying (Y).Usia (X2) berpengaruh negatif dan signifikan terhadap impulse buying (Y).Gender (X3) berpengaruh positif dan signifikan terhadap impulse buying (Y)

\section{DAFTAR PUSTAKA}

Ali, Asim, dan Saf Hasnu. (2013),

"An AnalysisOf Consumers'Characteristics On Impulse Buying: Evidence From

Pakistan".Interdisciplinaryjour nalOf Contemporaryresearch In Business. Juni 2013, Vol. 5, No. 2

Arikunto, Suharsimi, (2010). Prosedur Penelitian.Edisi revisi 2010, PenerbitRineka Cipta, Jakarta

Bashar, Abu., Irshad Ahmad, dan Mohammad W. (2012). A Study Of Influence Of Demographic Factors On ConsumerImpulseBuying Behaviour.InternationalJourna $l$ of Management andStrategy(IJMS) 2012, Vol. No.3, Issue 5, July-Dec.2012.

Bayley, Geoff and Clive Nancarrow. 1998. Impulse Purchasing: A QualitativeExploration of The Phenomenon. An International Journal. MCB UniversityPress. ISSN 1352-2752. Vol. 1 No. 2 1998 pp. 99-114.

Bellenger, D., Robertson D. H., dan Hirschman E. C., (1978). “ $A n$ Impulse Buying Varies by Product". Journal of Advertising Research, Vol. 18, Desember, pp. 15-18.

Bitner, M.J., Booms, B.H. and Tetreault, M.S.,1990.TheService Encounter:Diagnosing Favorableand Unfavorable Incidents, Journal of Marketing,Vol.54, pp. 71-84. 
Cobb, C. J. and Hoyer W. D. (1986). A Planned Versus Impulse Purchase Behavior. Journal of Retailing. Vol. 62, Winter, pp.67-81. [Online]. Diakses 3 Maret 2014.

Coley, Amanda, and Brigitte Burgess. 2003. Gender Differences in Cognitive and Affective Impulse Buying. Journal of Fashion Marketing and Management, Vo. 7No. 3, pp. 282-295.

Consumer Buying Habits Study, Point-of-Purchase Advertising Institute and Meyers Research Center, 1995

Engel, James F, et.al., 1995, Consumen Behavior, Alih Bahasa: Budiyanto, Jilid 1dan 2, Bina Rupa Aksara, Jakarta.

Fitriani, Rahma. (2010). Studi Tentang Impulse Buying pada Hypermarket di Kota Semarang. Skripsi: Program Sarjana (S1) Fakultas Ekonomi Universitas Diponegoro.

Ghani, Usman dan Farzhan A.J. (2010). An Exploratory Study of the Impulse Buying Behaviour of Urban Consumers in Peshawar.International

Conference on Business and Economics Research

Ghozali, Imam 2005. Aplikasi anasilis Mulitivariate Program SPSS.

BadanPenerbitUniversitas

Diponegoro, Semarang.

Hawkins, Mothersbaugh, Best, 2007, ConsumerBehavior:Building Marketing Strategy, McGrawHill, New York.

Japarianto, Edwin dan Sugiono Sugiharto, 2011, Pengaruh Shopping LifeStyle dan Fashion Involvement Terhadap Impulsif
Buying BehaviorMasyarakat High Income Surabaya. Journal Manajemen Pemasaran, Vol. 6, No. 1 April, pp. 31-41.

Kotler dan Keller, (2012).Marketing Management Edisi 14, Global Edition.Pearson Prentice Hall.

Kotler, Philip. (2004)Manajemen Pemasaran, Edisi milenium. Penerbit PT. IndeksKelompok Gramedia, Jakarta

Krisnawardhani, Tanti., Nur salam., dan Dewi Anggraini. (2010). Analisis Regresi Linear Berganda dengan Satu Variabel Boneka (Dummy Variable) Jurnal Matematika Murni dan Terapan Vol. 4 No.2 Desember 2010: 14 - 20.

Loudon, David L. dan Albert J. Della Bitta. (1993). Consumer Behavior. 4th Ed. McGraw Hill. Lumintang, Fenny Felicia. (2012). Pengaruh Hedonic Motives Terhadap Impulse Buying Melalui Browsing dan Shopping Lifestyle Pada Online Shop. Jurnal Universitas Katolik Widya Mandala Surabaya. Vol. 1, No. 6

Malhotra Naresh K, 1996.Marketing Research. An Applied Orientation, NJ, Prentice Hall, Inc.

Malhotra Naresh K, 2009. Riset Pemasaran Pendekatan Terapan, Edisi 4. Penerbit PT. Indeks,

Mowen, John C. dan Michael Minor, 2002,

PerilakuKonsumen,Jakarta: Erlangga.

Munir, Abdul Razak. (2012) Aplikasi Analisis Faktor Untuk Persamaan Simultan Dengan SPSS Versi 12. Laboratorium 
Manajemen Fakultas Ekonomi Unhas.

Mussry, Jacky.(2004) Menangkap Dinamika Sukses Bisnis Fashion. SWA [online] Diakses tanggal 4 Mei 2014melalui http://202.59.162.82/swamajala $\mathrm{h} /$ sajian/details.php?cid=1\&id= 513

Rahmasari, Lisda.2010.Menciptakan ImpulseBuying.MajalahIlmiah Informatika, 1(3), hal: 56-68.

Solomon, M.R. \& Rabolt, N. (2009). Consumer Behavior in Fashion, 2nd Edition. USA: Prentice Hall.

Sugiyono. (2010). Metode Penelitian Kuantitatif Kualitatif \& RND. Bandung: Alfabeta.

Sumarwan, Ujang. (2011) Riset Pemasaran dan Konsumen. Bogor: IPB Press

Suwanvijit, Wassana dan Sompong Promsa-ad. (2009). The Insight Study ofConsumer Life-styles and Purchasing Behaviors in Songkla
Province,Thailand.Internation

al Journal of Marketing Studies Vol. 1, No. 2, November 2009: 66-73.

Utami, Sri dan Sumaryono.(2008), "Pengaruh Gaya Hidup, Konsep Diri, Kepribadian dan Respon Atas Iklan Terhadap PreferensiMerek Ponsel Nokia", Vol 10(1) Hal: 65-76.

Wathani, Fikrah. 2009. Perbedaan Kecenderungan Pembelian Impulsif Produk Pakaian Ditinjau Dari Peran Gender. SkripsiSarjana Jurusan Psikologi pada Fakultas Universitas Sumatera Utara, Sumatera Utara.

Widayat. (2004). Metode Penelitian Pemasaran. Malang: UMMPress

Wood, M. (1998). Socioeconomic Status, Delay of Gratification, and Impulse Buying. Journal of Economic Psychology, 19 (3), 295-32. 